\title{
The Limits of territorially-focused conservation: \\ A critical assessment based on cartographic and geographic approaches
}

\section{HELEN D. HAZEN}

Corresponding Author: hazen@macalester.edu

\section{LEILA M. HARRIS}

Final version: Hazen, H., \& Harris, L. (2007). Limits of territorially-focused conservation: A critical assessment based on cartographic and geographic approaches. Environmental Conservation, 34(4), 280-

290. doi:10.1017/S0376892907004237

Citations of this work should use the final version as noted above 


\section{Table of Contents}

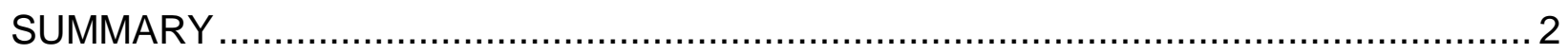

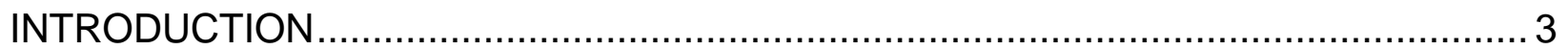

I. LIMITATIONS OF TERRITORIALLY-FOCUSED CONSERVATION: GEOGRAPHIC AND CARTOGRAPHIC INSIGHTS . .4

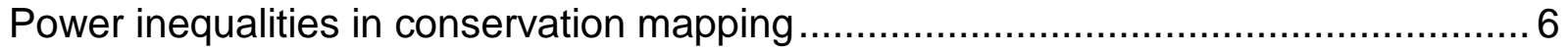

Effectiveness and effects of mapped conservation spaces ................................. 8

II. RESPONSES AND KEY DEBATES FROM THE CONSERVATION SCIENCES ..... 10

Systematic and eco-centric conservation planning .............................................. 10

People and protected areas management ............................................................ 11

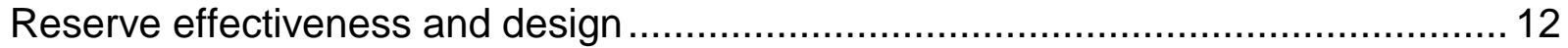

III. REVISITING CARTO-GEOGRAPHIC APPROACHES TO CONSERVATION

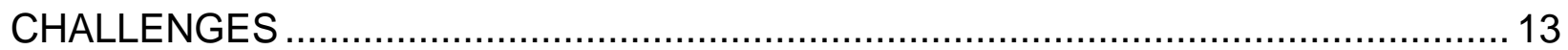

Strategies that upset eco-social inequalities .................................................. 13

Overcoming limitations of conservation mapping: Engaging cartographic and GIS

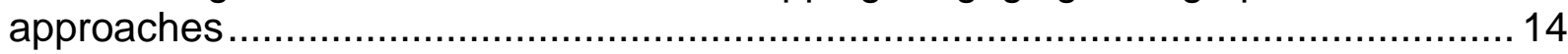

Overcoming limitations of the contemporary patchwork of conservation areas ......... 15

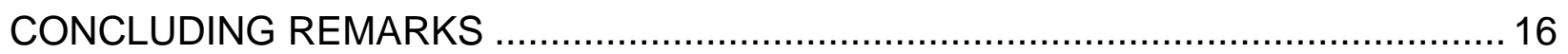

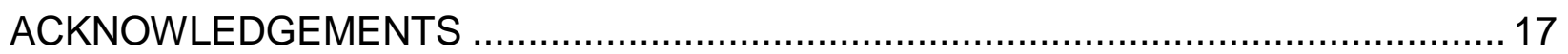




\section{SUMMARY}

This paper provides a critical assessment of territorially-focused conservation practice from geographic perspectives, focusing particularly on the influence of cartography. Specifically, we highlight ways that contemporary mapping technologies and practices can privilege territorial conservation approaches, perhaps at the expense of other possibilities, as well as other ways that mapping conditions the flexibility and types of conservation feasible. For instance, how might mapping practices lead to an emphasis on certain species, ecosystems, or conservation concepts over others? How appropriate is the static idea of a mapped conservation space for fluctuating environmental conditions and changing threats? Understanding that many of the challenges outlined here are acknowledged by conservation practitioners, we provide a brief sketch of ways in which these concerns are currently addressed in the conservation biology literature. In the final section, we return to our focus on geography and cartography to consider how advances in these fields might proffer further solutions that could be engaged to assist in confronting these conservation challenges. Our goal in highlighting these critiques and potential solutions is to identify gaps and opportunities that would benefit from increased interdisciplinary engagement across conservation, geographic, and cartographic fields.

Key Words: Boundaries, Cartography, Conservation, Geography, Map, Protected area. 


\section{INTRODUCTION}

The operation of many conservation programs is inherently spatial, from the designation of protected areas to the zoning of land uses. Spatial approaches have become particularly significant in prioritizing conservation target areas, and are now used by most of the major conservation non-governmental organizations (NGOs) to direct funding (Whittaker et al. 2005). The recent proliferation of GIS (geographic information science) technologies has further encouraged the use of geographic and cartographic tools in conservation planning. The linking of conservation goals to specific territories ('mapping for conservation') is a practice that finds expression in a rapidly expanding map of protected areas. In 2006 the World Database on Protected Areas listed 22,082 national and 946 international terrestrial protected areas, collectively covering over $8 \%$ of the earth's land surface (WDPA 2006). As Woodley (1997, p.11) suggests, the designation of protected areas has become "the most common human response to human induced ecosystem degradation."

Part of our aim in this paper is to critically assess this strong reliance on the designation of geographical areas for conservation. We do so by emphasizing issues related to space, boundaries, scale, and political ecology - all central to the geographic literature. In addition, we are particularly attentive to cartographic dimensions of conservation, detailing how mapping techniques and technologies can influence conservation approaches. Of the issues we raise, many are also central themes from the conservation sciences. For instance, a great deal of work has considered reserve design and effectiveness, and the distinct challenges that future environmental changes may pose for geographically-limited reserves (e.g., Newmark 1995; Noss 2001; Hannah et al. 2007). Further research in conservation biology and ecology has sought to combat such limitations via concepts such as buffer zones, landscape permeability, continentalscale conservation, and systematic conservation assessment (e.g., Theberge 1989; Shafer 1999; Margules \& Pressey 2000; Noss 2000; Hannah et al. 2007). We consider that attention to limitations highlighted through cartographic and geographic concepts and approaches will illuminate further gaps and opportunities in these respects.

Throughout the piece, we use the term 'conservation mapping' to highlight a complex of interrelated spatial and territorial strategies common to contemporary conservation practice. These include: the designation of geographic areas as relevant for conservation (protected areas), the delimitation of practices that are considered to be appropriate with respect to those areas, and cartographic representation of those associations.

Our argument is structured in three parts. In part one, we consider geographic discussions of the limitations of territorially-focused conservation, highlighting issues related to social equity, the role of boundaries, and cultural and political influences on protected area designation. We turn in part two to a brief summary of current work from the conservation sciences that tackles these challenges. Finally, in part three, we return to cartographic and geographic concepts and technologies to highlight how further engagement with these approaches might complement existing strategies. Elements of these arguments are included in an article published with the online journal, Acme: An International E-Journal for Critical Cartographies (Harris and Hazen 2006). By reframing 
our ideas and extending their potential readership via Environmental Conservation, we hope to encourage inter-disciplinary conversation on these issues to enable further cross-pollination of ideas between geographic, cartographic, and conservation sciences.

It must be emphasized at the outset that our discussion of the limitations of conservation mapping is not to argue against the designation of conservation territories. Rapid global biodiversity loss is clearly an issue of critical concern (Whittaker et al. 2005), with over 30,000 species of plants and animals currently listed by CITES as endangered, threatened, or at risk of overexploitation (CITES 2006). In light of the rapidity and extent of such losses, protected areas have served an important role in stemming species losses and protecting ecosystems from further degradation (Naughton-Treves et al. 2005). Given that fragmentation, habitat loss, and ecosystem degradation are leading threats to many species, protected areas are valuable tools for protecting underlying ecological processes and functions and maintaining biological integrity and resiliency at a variety of different scales (Balmford et al. 1998; Groves et al. 2002). In addition, protected areas may also be the most cost-effective approach for conserving biodiversity (Balmford et al. 1995). There are therefore very logical underpinnings to territorially-focused conservation strategies, and they remain a critical component of any sound biodiversity conservation strategy (Soulé \& Terborgh 1999). Nonetheless, they also have their shortcomings. As Ervin $(2003,819)$ points out, for instance, "as a whole, protected areas worldwide have inadequate design and coverage, lack sufficient management to address a host of threats, and face increasing levels of environmental degradation." Given challenges, such as these we consider continued discussion of limitations of territorial strategies valuable, particularly in ways that seek to foster further interdisciplinary engagement to more adequately address these shortcomings.

\section{LIMITATIONS OF TERRITORIALLY-FOCUSED CONSERVATION: GEOGRAPHIC AND CARTOGRAPHIC INSIGHTS}

Geographic and related literatures have focused on three main limitations of territorial approaches to conservation. First, protected areas form a patchy approach to conserving natural landscapes with considerable inequalities with respect to which areas are protected, and which are not. These variations are often better explained by historical, cultural, economic, and political processes than by ecological imperatives. Second, protected areas have often resulted in unequal outcomes for different social groups, highlighting the need to analyze conservation mappings in relation to social justice. Finally, practical shortcomings exist in terms of the effectiveness of protected areas that relate to issues of spatial and temporal flexibility, the role of boundaries, scale, and other key geographic concepts. We will consider each of these issues in turn. Although not all of the scholars that we cite here are geographers, the issues discussed here nonetheless provide a sense of what geographic approaches lend to these discussions. 


\section{Geographic differences and preferential mappings}

Many assessments of areas designated for conservation have suggested that the current array of conservation areas is not based solely on ecological value, but fundamentally in relation to cultural and economic imperatives (Margules \& Pressey 2000 ). In the traditions of environmental history, landscape studies, and peopleenvironment geography, it has been argued that landscapes preferentially selected for protection are typically those that are considered to be dramatic or of high recreational value (Vale 1988; Zimmerer et al. 2004). For instance, Cronon (1995), considering parks in North America, suggests that landscapes widely deemed to be 'sublime' are favored over other landscapes that may have comparable or greater ecological importance. Related discussions highlight ways in which particular visions of 'nature' or 'wilderness'-especially notions of pristine nature that underwrite many conservation strategies-are necessarily intertwined with social, economic, cultural, and historical processes (Cronon 1995; Braun \& Castree 1998). Ridder (2007, 9), for example, discusses how notions of 'naturalness' are often defined according to particular historical benchmarks; for instance, an area may be considered 'natural' if it conforms to visions of a pre-industrialization landscape, despite growing awareness that preindustrial landscapes were also heavily modified by human activities. On a global scale, too, expectations of naturalness and wilderness can be seen through an emphasis on the protection of widely-publicized conservation targets, such as tropical rainforests, over other biomes like grasslands that have not received such focused attention (Hazen \& Anthamatten 2004). Given such debates related to which visions of nature we want to 'conserve,' and the way that these vary according to cultural and social attributes, it is clear that conservation decisions are not value-free (Whittaker et al. 2005). In response, increasing efforts are being made within the conservation sciences to try to make future conservation decisions more systematically (Margules \& Pressey 2000), as discussed in part two.

Addressing these issues from a cartographic approach, an issue that has not yet been explored in the literature is the degree to which areas may also be selected for protection due to their relative 'mappability.' For instance, grasslands are not only less 'sublime' than many other landscapes, but are also less definable in cartographic terms (less 'mappable') than clearly-bounded features such as lakes, islands, or even forests. The case of marine ecosystems is noteworthy in these senses, with data limitations, mobile features, and other social and political considerations contributing to the difficulty of mapping and managing ocean features (Steinberg 2001), and perhaps helping to explain why marine ecosystems have not seen the same proliferation of protected areas over the past twenty years that has occurred in terrestrial areas. Related to this, accessibility is a further clear geographical challenge to successful conservation with remoter areas less likely to have sufficient data available for effective mapping projects. Reddy and Dávalos (2003), for instance, found spatial sampling biases in the intensity of biodiversity data collection in sub-Saharan Africa, with significantly more data available for sites near urban areas and in more accessible regions, presenting clear potential for priority-setting activities using these data to be inaccurate or skewed.

Another clear influence on conservation mappings is pre-existing political and 
administrative boundaries, which may influence how conservation boundaries are drawn, potentially resulting in the neglect of certain important ecosystems (Hanks 2000). For instance, consider the frequency with which jurisdictional boundaries define at least one edge of a protected area. In such cases, political boundaries define reserves, without regard for ecological conditions. Fagergren (1998) details the sort of complications that arise when trying to mediate this complexity of administrative boundaries, demonstrating the complex interplay between conservation mappings and other priorities.. In what he calls "The Great Compromise," he describes how the boundaries of Big Cypress National Preserve in Florida were finally drawn to account for local township lines, lands suitable for a jetport, hunting camps, indigenous claims, and private land ownership.

Extending our line of argument related to the relative mappability of geographic features, it is easy to imagine ways that conservation practice might also be weighted preferentially towards those concepts and practices that are most readily expressed in map form, particularly as mapping practices hold cachet scientifically and politically (see Nietschmann (1995) for further discussion of the 'power of maps'). The idea of 'biodiversity hotspots' is a case in point. Here, attention is focused on limited areas that are considered to harbor very high levels of biodiversity as targets for protection (Myers et al. 2000). The cartographic nature of this approach can be seen as garnering support for the idea as the strategy can be displayed to a lay audience in a way that makes its scientific rationale easily comprehensible. Specifically, the limited geographic extent of hotspots contributes to a sense that the idea is not only feasible but even politically attractive in terms of maximizing returns on conservation investments. There is no doubt that this approach has been successful, with funders supporting hotspot conservation measures to the tune of $\$ 750$ million, according to Brooks et al. (2006). However, given that there are important critiques of the hotspots approach, for instance, suggestions that it may turn attention away from other important conservation targets and wider conservation goals (Kareiva and Marvier 2003), there is reason to be attentive to ways that mapping may entrench support for particular visions of conservation, at the same time turning attention away from alternative strategies.

\section{Power inequalities in conservation mapping}

Another theme that has been important to the work of geographers is consideration of the social and political implications of conservation area designation and management. The political ecology literature, in particular, details instances where certain social groups, livelihoods, or forms of knowledge are excluded or marginalized by the creation of particular conservation areas, particularly when the conservation boundary is policed in strict fashion (e.g., Neumann 1992, 1995; Peluso 1993; Colchester 1996; Katz 1998; Turner 1999). For instance, Turner (1999) describes how unsubstantiated claims about pastoralists competing with wildlife in Southwestern Niger have resulted in the strict exclusion of local people from a reserve (ironically exacerbating threats to wildlife), while Peluso (1993) highlights connections between monitoring the boundaries of conservation areas, and violence against local populations. These and similar studies have underscored the need to examine assumptions about local populations in 
conservation planning and the creation of protected areas (Agrawal \& Gibson 1999; Weis 2000).

A related discussion considers how different forms of knowledge are valued unequally, with important implications for the mapping, designation, and maintenance of conservation spaces. A critique common to these discussions is that Western or techno-scientific ideas are often treated preferentially over traditional or indigenous ways of knowing, even though traditional knowledge systems may involve complex understandings of ecosystem processes (Berkes et al. 1998). As just one example among many that considers the importance of these issues for park design and management, Goldman (2003) describes the exclusion of Maasai knowledge in conservation efforts in Northern Tanzania. She argues that this exclusion has further marginalized the Maasai, as well as discouraged more flexible land-use management practices to which local knowledge may be particularly well-suited. Along similar lines, and highlighting our focus on mapping, there is also increasing attention to the possibility that technologies such as GIS exacerbate these trends by further cleaving distinctions between 'expert' and 'lay' or 'indigenous' knowledge. In response, a considerable literature has developed considering how alternative mapping practices can be revalued, and mapping democratized via notions such as participatory GIS, as discussed in part three (Armbrecht Forbes 1995; Arvelo-Jimenéz and Conn 1995; Nietschmann 1995).

Related to our earlier discussion of why the current configuration of conservation areas has emerged rather than other possible arrangements, geographical approaches have also emphasized social and political inequalities to explain these differences. For instance, concerns have been raised that neo-colonial relationships may be perpetuated by the actions of the large conservation organizations of the industrialized North as they operate in the global South (Chapin 2004). For instance, in his analysis of eastern Africa Neumann (1997) notes that over $10 \%$ of territory in some African countries is now managed by state and international organizations for conservation purposes. He goes on to raise the critique that conservation territories can consolidate and extend state control over land, shifting control over resources away from local people. While this critique is valid, it is notable that when analyzing the current map of conservation areas globally, the countries with the highest proportions of land protected are actually often in the industrialized North. However, this too can be seen as a reflection of how political structures, recreational opportunities, or conservation awareness may be more influential in the determination of conservation areas than are biodiversity imperatives per se (see also Zimmerer et al. 2004; Naughton-Treves et al. 2005). It is also somewhat problematic, given that $90 \%$ of annual conservation funding is estimated to originate and be spent in economically rich countries (Brooks et al. 2006), while the majority of conservation needs are considered to be in developing countries (Smith 2003). These additional examples add weight to the critique that political conditions, economic inequalities, histories of colonialism, and uneven relations of power are fundamental to understanding the contemporary map of conservation areas. 


\section{Effectiveness and effects of mapped conservation spaces}

Another broad area of enquiry from a geographic perspective relates to the effectiveness of, and effects of, protected areas. These discussions evaluate the role that mapped conservation spaces play, their relative effectiveness for different conservation goals, and other political, social, or ecological effects that reliance on territorial conservation strategies may engender. Initiating these discussions, conservation practitioners have already detailed a number of ways in which protected areas are relatively ineffective. For instance, park boundaries are often unable to prevent the entry of threats, whether pollution, invasive species, or poachers (Woodley 1997).,We are also increasingly aware that mapping areas for conservation may be unable to protect species and ecosystems from broader environmental challenges, such as global warming or extreme weather events (Noss 2001). By contrast, conservation boundaries can also be overly effective, for instance, severing ecological units (Theberge 1989) or creating deleterious consequences at their edges (Moenting and Morris 2006). Over time, a conservation boundary may even appear to 'come alive' through markedly different vegetation characteristics or land uses on either side.

Adding to these ideas, our focus on carto-geographic contributions suggests that mapping an area for conservation can also be overly 'effective' at more abstract levels. Specifically, mapping areas for conservation can implicitly suggest that relationships between species, ecosystems and territory are fixed in space, and even that they will remain so into the future, contributing to static understandings of the environment that counter the inherent dynamism and flux of ecological conditions and conservation requirements (Zimmerer 2000). While ecologists may be well aware of these challenges, bureaucratic channels rarely have the capability to cope with flux and uncertainty and so mapped spaces can take on a life of their own. As evidence of such, Vandergeest (1996) describes how mapped locations of forests in Thailand, over time, came to legally define 'forests' for state agencies, regardless of the actual vegetation found in those regions. Consider also the possibility that mapping an area as 'wildlife reserve' may create a false sense of security concerning our ability to achieve conservation goals, giving the impression that conservation has already happened and is successful (consider the use of the past tense in the term protected area). The number of 'paper parks,' which "enjoy only a virtual existence as lines drawn on official maps" (Terborgh and van Schaik 2002, 4) but lack sufficient institutional capacity or funding to support their protected status are surely convincing evidence of such concerns.

A further issue of concern is that through designation of particular areas as conservation spaces we may be concurrently - albeit unwittingly -implying that other areas are less worthy of protection (Boothby 2002). As such, Zimmerer $(2000,362)$ argues that the designation of conservation zones can be taken to justify human use, and over-use, of land outside the boundaries:

Ever-growing contrasts separate the worsening degradation of many environments (including those of spatially distinct sacrifice areas) from the territories of today's conservation boom. Discursively too, the boundaries of conservation areas seem to cleave apart the privileged spaces of nature 
protection and preservation from those places of heavier human use and inhabitation.

The case of Costa Rica is instructive on this point. While Costa Rica is proportionally well protected compared with other Latin American countries, in the 1990s it also experienced among the highest rates of deforestation owing to rapid depletion of forests outside these protected areas (Vandermeer and Perfecto 1995). Responding to these possibilities, Clapp (2004) suggests that parks need not be viewed as bounded spaces with everywhere else defined as 'unnatural.' Instead, they should be considered as core areas around which natural resources must be managed effectively across broader geographic ranges, reflecting similar discussions concerning continental scale conservation in the conservation sciences.

Finally, the mapping of conservation spaces can also alter our perceptions of an area, creating new psychological associations. For instance, when Yellowstone National Park was founded in 1872, long-term human use of the land was effectively erased when Native American communities were displaced in order to create the new national park. Similarly, the founding of Great Smoky Mountains National Park involved the removal of pioneer settlements to comply with visions of pristine and uninhabited nature. The 'myth' of wilderness that informed these actions was central to the creation of US national parks and has helped to perpetuate the idea of people as separate from nature (Cronon 1995; Spence 1999). In such contexts the mapping of a certain space as 'wilderness' or 'nature reserve' can be taken as implicit endorsement of the need to separate humans from nature-a clear contrast with ongoing efforts to better integrate populations with conservation spaces.

A fundamental point to be distilled from these divergent debates is that conservation maps, as other maps, are necessarily reflective of and productive of power (cf. Harley 1989). Just as cartographers necessarily privilege compass direction, area, or other aspects in creating maps (Monmonier 1996), those who engage in conservation mapping necessarily privilege certain species or understandings of nature over others. Further, the technological and scientific aspects of cartography have great political weight, at times encouraging the use of cartographic techniques over other approaches or forms of knowledge. Given the many limitations of territorially-focused conservation, it is crucial to recognize the degree to which mapping technologies, and computerassisted technologies like GIS in particular, may serve to formalize and legitimize territorial approaches to conservation-with the concurrent potential to sideline other non-territorial strategies. It is also noteworthy that many features of critical importance to the success of protected areas are relatively 'unmappable'-for instance a region's social and political infrastructure-and may be neglected in a techno-scientific climate that overemphasizes what we can achieve with innovative technological tools. Our hope is that greater acknowledgement and recognition of these types of issues might encourage more transparent and explicit decision-making with respect to conservation goals. Just as mapmakers must select particular cartographic projections that favor area, size, compass direction, or shape-conservation practitioners might similarly be explicit with respect to which conservation goals are prioritized or likely to be met with 
particular conservation mappings. This would help to counter the false impression that all elements of a system can be preserved equally well under the banner of 'protected area.'

\section{RESPONSES AND KEY DEBATES FROM THE CONSERVATION SCIENCES}

While often using different language and approaches, many of these issues are already being addressed in earnest within the conservation sciences. For example, conservation practitioners are keenly aware of challenges with respect to park boundaries and limited conservation networks that are unlikely to remain effective over long time frames (see Shafer 1999; Noss 2001; Hannah et al. 2007, among others). Indeed, as we discuss below, much attention of late has focused precisely on the question of how to design protected areas that can remain flexible over time, as well as to how to more effectively prioritize conservation strategies given that meeting all conservation goals is impossible in the face of financial, political, and other constraints.

We outline here three areas of research from the conservation sciences that directly address the three major areas of concern from the geographic literature, outlined above. First, in response to criticisms that conservation territories have traditionally been selected on ad-hoc or overly political bases, efforts have aimed to make the selection of conservation spaces more eco-centric and systematic. Second, related to the critique that conservation areas have often worked to the detriment of local populations, at times with perverse consequences for conservation goals, considerable efforts are underway to reincorporate people back into protected area management plans and planning. Finally, in response to criticisms of the ineffectiveness of protected areas, a considerable literature aims to assess and improve protected area design and management via innovative concepts such as fuzzy boundaries and landscape permeability. In addition, responding to mounting empirical evidence of the need for spatio-temporal flexibility, efforts are ongoing to make protected area networks more adaptive and resilient.

\section{Systematic and eco-centric conservation planning}

Recognizing the degree to which protected areas are often designated and managed according to shifting notions of appropriate or desirable nature, calls have intensified for more eco-centered and systematic approaches to conservation planning (e.g., Theberge 1989; Woodley 1997; Simberloff 1998; Margules \& Pressey 2000). However, even when considering only ecological goals, prioritization is far from straightforward. Not only are there complex and contradictory challenges in meeting the needs of only non-human components of ecosystems (Schwartz 1994), but protected area outcomes also vary significantly depending on the priorities used (Whittaker et al. 2005). For instance, should we be striving towards representation of as many different ecosystems 
as possible in an array of protected areas (see Ricketts et al. 1999), or is it more expedient to focus attention on biodiversity hotspots (see Myers et al. 2000)? An extensive conservation literature has now emerged that focuses on priority-setting in conservation area designation, design, and management (see Johnson's 1995 review).

As Margules \& Pressey (2000) point out, existing reserve systems are biased towards protecting particular types of ecosystems, often those in remote areas and that are unsuitable for commercial activities. For instance, Scott et al. (2001) determined that over a quarter of US protected areas are situated in areas with the least productive soils and over half are at elevations over 2400 meters. Others have noted a bias towards the conservation needs of large mammals, and other charismatic or easily-measured forms of biodiversity, at the expense of other important aspects of an ecosystem, which may face even greater threats (Lawler et al. 2006; Simberloff 1998). The notion of systematic approaches to locating and designing reserve systems has emerged in response to observations such as these. Systematic conservation assessment aims to use objective measures and reserve selection algorithms to assess the relative merits of different candidate areas with respect to their ecological value (Margules \& Pressey 2000; Pressey \& Cowling 2001; Moore et al. 2004). Such approaches are often computerbased but may be coupled with procedures to try to develop sound implementation strategies and stakeholder collaboration (Knight et al. 2006). These efforts move beyond traditional single species-focused conservation approaches, to recognition that biodiversity more broadly is a critical variable (Groves et al. 2002), underscoring the need for regional, rather than local, goal-setting. Assessing the somewhat intangible notion of 'biodiversity' has emerged as a secondary challenge in efforts to use systematic ecological criteria for prioritizing conservation sites. In response, a considerable literature details approaches and shortcomings to trying to identify measurable proxies that effectively summarize overall ecological diversity (Andelman \& Fagan 2000; Hess \& King 2002; Kintsch \& Urban 2002; Lombard et al. 2003; Coppolillo et al. 2004; Cowling et al. 2004).

\section{People and protected areas management}

As a second issue related to the challenges of territorially-focused conservation, there is increasing attention to the need to focus on the interface between people's needs and interests in protected area design and management. This integration is viewed by some as essential both to the promotion of human well-being and to ensuring that biodiversity and conservation needs are met in the long-term (Sinclair et al. 2000; Shafer 1999), particularly as "declining biodiversity and the poverty and marginalization of remote communities are connected" (Sheil et al. 2006, p.17). Attention along these lines has focused both on the importance of resources and access for local populations, as well as considerable evidence of the role that socio-political factors play in the success and persistence of conservation areas (see O'Connor et al. 2003).

Although there remains considerable controversy within the conservation community about how and if people should be incorporated back into protected areas (Brandon et al. 1998; Terborgh \& van Schaik 2002), as well as concerns that expecting conservation 
to also meet social and economic equity goals may be unreasonable and overly ambitious (Naughton-Treves et al. 2005), there is growing awareness that conservation areas are nonetheless embedded in human dominated landscapes (Zander \& Kachele 1999; Curtin 2002; Sanderson et al. 2002). Indeed, conservation efforts may be even more important in densely-populated areas considering the large numbers of threats in these places (Ricketts \& Imhoff 2003). Such issues provide clear opportunities for fruitful interdisciplinary engagement.

\section{Reserve effectiveness and design}

Owing to the many challenges of a limited network of protected areas, and particular challenges that come with separating activities within and without protected areas, it is clear that mapping for conservation poses key dilemmas-the goal is to preserve natural systems, yet the imposition of boundaries may disrupt processes that are critical to the evolution and maintenance of biological diversity. Not surprisingly, a wide variety of strategies have been suggested to improve the form and function of protected areas. Strategies proposed have included efforts to improve protected area design to reduce the negative effects of habitat fragmentation via concepts such as wildlife corridors and buffer zones (Beier and Noss 1998; Shafer 1999; Berger 2004), and efforts map park boundaries in line with natural features, such as drainage basins (Theberge 1989). In response to evidence that protected areas are likely to lose species over time without extensive and varied ranges (Newmark 1995), there is also increasing attention to moving beyond the limited and fragmented network of protected areas towards management at regional or continental scales (Ricketts et al. 1999; Groves et al. 2000). More specifically, emphasis has been placed on landscape permeability, connectivity and flexible boundaries, as well as on the creation of transboundary protected areas that would minimize the impacts of arbitrary international frontiers on protected areas (e.g., Theberge 1989; Danby 1997; Noss 2001; Hanks 2000; Roberts et al. 2003; Berger 2004).

In addition to efforts to deal with broader spatial scales, there are also strategies to engender greater spatial and temporal flexibility in park design and management. In particular, considerable work has dealt with the challenge of making protected areas more adaptive with respect to large-scale or long-term environmental changes (particularly climate change) although many of these approaches are, as yet, largely untested (Halpin 1997; Soto 2001). For example, Hannah et al. (2007), noting that species are unlikely to remain 'in place' pending climate change, suggest that protected area networks could nonetheless remain effective into the future if designed with this in mind. Species range shifts could be modeled and then reserve selection algorithms used to try to assess the effectiveness of protected areas under particular environmental scenarios (Pressey and Cowling 2001; Hannah et al. 2007). All of these efforts constitute a mounting response to the limitations of fragmented and overly-fixed conservation mappings. 


\section{REVISITING CARTO-GEOGRAPHIC APPROACHES TO CONSERVATION CHALLENGES}

While there have clearly been considerable advances from the conservation sciences related to overcoming limitations of contemporary conservation mappings, we argue that continued and broader engagement with advances in geography, and particularly those in cartography and GIS, offer further promise. As such, we offer a discussion here of possible starting points for such enhanced disciplinary engagement. There are several key ways that carto-geographic approaches offer potential: (1) efforts that explicitly seek to promote more effective or just conservation in ecological, social and political senses, (2) efforts to improve the form and function of conservation territories to engender greater spatial and temporal flexibility, and (3) exploration of alternative approaches that attempt to move beyond territorial approaches to conservation. While we acknowledge that tension and overlap clearly exist among these approaches, and we recognize that geography, cartography, and GIS already play a significant role in conservation planning and management, we hope that this discussion will illuminate possible points of intersection that will continue to benefit from deepened collaboration across the cartographic, geographic, and conservation sciences.

\section{Strategies that upset eco-social inequalities}

In line with efforts to improve equality in ecological senses via more systematic selection of reserves, mapping and its associated tools are being increasingly used to assess representativeness of coverage of protected areas (Olson et al. 2001; Hazen \& Anthamatten 2004). GIS is now commonly used to identify 'gaps' in protected area systems via the rapidly expanding field of gap analysis (Savitsky 1998), and other projects have been initiated to try to assess spatial patterns of protection globally. For instance, the World Wide Fund for Nature's Global 200 survey identifies areas around the world that would help to improve coverage of global ecosystems among protected areas (Olson and Dinerstein 1998). GIS techniques have also been used to assess equality of conservation coverage in broader senses. For instance, Halpern et al. (2006) in their assessment of how conservation funds are spent by large conservation organizations used GIS data to assess the degree to which global priority maps guide conservation spending, while Reddy and Dávalos (2003) used GIS data to investigate whether sampling bias skews which areas are prioritized for conservation.

Geographic approaches have also been used to try to reduce inequalities in social senses. As noted, many theorists suggest that meeting the needs of local populations may actually improve the ability to meet conservation goals over the long term, for instance through minimizing unregulated access (Turner 1999), or by achieving more robust and democratic resource management mechanisms (Agarwal 2001). In response to such ideas, a complex of approaches has emerged that attempt to soften the divide between protected areas and the needs of local populations: 'multiple-use conservation areas,' 'integrated conservation development projects,' and 'nature-society hybrids,' for instance (Zimmerer 2000; Clapp 2004). These ideals of integrating local interests and 
conservation needs have not gone unquestioned, of course, as goals of local people and conservationists do not necessarily intersect (Brandon et al. 1998). Although conservation areas will never be able to achieve all social and ecological goals (Naughton-Treves et al. 2005), discussions and efforts along these lines must proceed if we are to avoid a future of protected areas as exclusionary fortresses (see Sunderlin et al. (2005) for further discussion of integrating livelihoods and conservation needs).

It is also important to note the considerable efforts underway focused on using cartographic tools and techniques to challenge social and political inequalities (at times referred to as counter-mapping, see Harris \& Hazen (2006) for discussion). For example, democratized mapping techniques or similar methods can be used to bolster resource access for indigenous groups or economically vulnerable populations (Nietschmann 1995; the Maya people of Southern Belize 1997). Other examples demonstrate how participatory mapping technologies and skills, or use of basic sketch maps, can be used to foster greater participation of local people in conservation efforts (Hodgson \& Schroeder 2002; Pintea, 2002). Recent efforts have also explored the specific ways that local and technical knowledge can be integrated, particularly for biodiversity aims (Anuchiracheeva et al. 2003; Balram et al. 2004). Attempts to promote popular access to powerful and persuasive cartographic tools raise their own concerns with respect to exploitation of local people as well as questions of data quality and robustness (Hodgson and Schroeder 2002). With serious attention to these concerns, however, there is still clear potential to extend such possibilities. As Nietschmann asserts (1995, p.37), "More indigenous territory can be reclaimed and defended by maps than by guns."

\section{Overcoming limitations of conservation mapping: Engaging cartographic and GIS approaches}

Building on the section above, there are many additional ways that carto-geographic approaches might be engaged more fully to further conservation goals. At a basic level, cartographers could contribute towards public knowledge campaigns through the production of visual representations to relay information about the urgency of species loss, drawing increased attention to conservation imperatives. GIS is already being widely used to focus conservation efforts by overlaying species' habitat requirements with information about climate, soil, human threats, social goals, or other conditions to highlight priorities (Mazzotta et al. 2002; Harris et al. 2005; Tchouto et al. 2006). Similarly, there have been efforts to use GIS and spatial modeling techniques to evaluate landscape permeability, migration pathways, and habitat analysis (Singleton 2002; Ray et al., 2002). GIS tools, in combination with recently-developed computational packages for statistical analysis, are also allowing more rigorous numerical analyses of data on species distributions than ever before (Tchouto et al. 2006). Use of GIS in these ways enables integration of complex biophysical species' requirements with knowledge of changing human needs and activities that are so influential in conservation outcomes.

More recently, advanced GIS technologies, such as real-time or frequently updated GIS 
data, modeling, and animated visualization techniques have been developed and hold clear potential to facilitate more flexible and dynamic conservation approaches. With such tools, the movements of certain protected populations can be monitored and the activities allowed within a certain area or zone modified accordingly. For example, if a conservation effort is focused on chimpanzee populations, cartographic tools might enable conservation strategies to be adapted dynamically to chimpanzee troop movements, changing habitat characteristics, or even fluctuating threats to chimpanzee populations. Applied to fisheries, new computer and mapping technologies have enabled commercial fishing fleets to monitor, track, and harvest fish populations more effectively. Similar technologies are now being engaged to ensure the protection of fisheries by monitoring school movement and enforcing non-harvest, or even by assessing marine conditions (such as temperature) to evaluate where fisheries are most likely to be productive (Valavanis et al. 2004).

Emerging cartographic and visualization technologies might also be employed to engender greater seasonal flexibility, with regulations relaxed in seasons or years when conditions are particularly favorable and tightened under stressful conditions. Such seasonal flexibility is already endorsed by a growing number of management authorities. For example, Royal Bardia National Park in Nepal adopted a seasonally flexible boundary, allowing villagers access at certain times of the year to collect plant products for their own use (Brown 1997). Similar suggestions have been made to allow seasonal passage of herders through park territories (Turner 1999) in order to mesh environmental management practices with social justice goals. Fuzzy boundaries and animated mapping can also serve efforts to conceptualize and manage boundaries that are less distinct, perhaps more consistent with buffer zones and similar notions. Without doubt, recent cartographic advances open up possibilities for more flexible and spatially-unfixed conservation strategies.

It is also of interest that concepts from geography and cartography suggest the possibility that conceptualizations of territory for conservation could be extended to involve a variety of different scales, rather than the human scales that frequently drive conservation mapping. For instance, Turner (2006) suggests that satellite imagery has enabled assessments of Sahelian conditions that deal more effectively with spatiotemporal variability. Developing cartographic techniques might also enable us to think through other scales that might be appropriate in certain circumstances, including micro- or global-scales.

\section{Overcoming limitations of the contemporary patchwork of conservation areas}

At a fundamental level, there are also more radical possibilities suggested by our geographic discussion of limits to territorially-focused conservation. Some of the critiques raised in the above discussion invite the exploration of possibilities that move beyond the very idea of the protected area. For instance, mapping and GIS technologies have helped to reveal the complexity and extent of many animals' use of the landscape, highlighting the need for extensive areas over which certain species can 
range, and the need for connections between ecosystems. This, coupled with greater understanding of the limitations of territorial approaches, could foster discussion of how to focus attention more centrally beyond protected areas towards the urban and agricultural landscapes that represent a large proportion of the earth's surface and the predominant landscapes in which most people live. As others have noted, attention could fruitfully be paid to improving conditions in urban or partially-degraded environments (Ricketts and Imhoff 2003; Lefroy \& Smith 2004), and to moderating human activity and consumption, rather than focusing so heavily on 'wilderness areas' (Cronon 1995). Boothby (2002, p.45), for instance, suggests that future conservation initiatives will depend more on stakeholder agreements than on simple "lines on maps," moving beyond the delineation of wildlife areas in a legal sense. Similarly, the European Union's Habitats directive, approved in 1992, aims to incorporate human activities that are not seen as a constraint to biodiversity into conservation approaches, replacing a previous policy that aimed to set nature aside from human activities (Alphandéry \& Fortier 2001).

With these examples, we are suggesting that there are likely to be a number of realms related to broader 'conservation' strategies, that are less focused on species needs, habitat, or protected areas, and more generally focused on consumption, waste reduction, or reduced energy reliance-all of which, over the long term are likely to serve biodiversity and conservation goals. To a certain extent this is the flip side to the idea of reincorporating people into protected areas; highlighting the possibility of focusing conservation strategies into heavily-peopled domains. Such strategies are consistent with a wide variety of schema underway, including clean air legislation, neighborhood parks, environmental education, and movements such as bioregionalism (McGinnis 1999). In all these ways, conservation can be extended beyond the limited idea of the 'protected area.'

\section{CONCLUDING REMARKS}

Evaluating territorially-focused conservation practices in light of insights from cartographic and geographic literatures offers several key contributions. Specifically, understanding mapping as central to the conservation toolkit enables explicit examination of the spatial and territorial underpinnings of conservation, as well as the limitations of an over-focus on territorial approaches. From this analysis, it is clear that there are several ways in which mapping and cartography have further retrenched certain territorial approaches to conservation, at times sidelining other forms of knowledge or approaches.

With attention to these issues, progress has been made toward overcoming the limitations of territorially-focused conservation, whether strategies to reduce the sharp edges of conservation boundaries or efforts to incorporate local people back into conservation management plans. Even with these advances, however, it is clear that continued efforts are needed. Among other insights that seem to offer promise, it seems that emphasis needs to be accorded to approaches that take into account whole 
systems and landscapes, rather than fragments thereof. This could take many forms, from transboundary reserves to continental-scale permeability for mega-fauna, to emphasis on urban ecologies and education campaigns. Although challenging, there seems also to be a strong imperative for conservation to foster and respect flexibility and dynamism, rather than pursuing static or fixed notions of spaces of conservation that are likely to be inconsistent with evolving ecological and social conditions. Further, efforts must continue to attempt to meet human needs and conservation goals together, rather than cleaving apart 'humans' from 'nature.' While attention to cartographic and geographic concepts highlights and underscores some of the limitations and problems inherent to contemporary territorial conservation strategies, we hope we have also shown that there is also considerable scope for cartographic and geographic approaches to contribute further to overcoming these limitations. It is our hope that this discussion offers some starting points for those working together from across the geographic, cartographic, and conservation fields.

\section{ACKNOWLEDGEMENTS}

The authors gratefully acknowledge the comments of a number of readers on earlier drafts of this article. In particular, thanks to Bruce Braun, R.Alex Clapp, Salvatore Engel Di Mauro, Mara Goldman, Mark Harrower, Sheila Hones, Lisa Naughton, Scott Prudham, Eric Sheppard, Matthew Turner, Gabriela Valdivia, and Connie Weil. 


\section{REFERENCES}

Alphandéry, P. \& Fortier, A. (2001) Can a territorial policy be based on science alone? The system for creating the Natura 2000 network in France. Sociologia Ruralis 41: 311-328.

Anuchiracheeva, S., Demaine, H., Shivakoti, G., \& Ruddle, K. (2003) Systematizing local knowledge using GIS: Fisheries management in Bang Saphan Bay, Thailand. Ocean and Coastal Management 46: 1049-1068.

Agarwal, B. (2001) Participatory exclusions, community forestry, and gender: an analysis for South Asia and a conceptual framework. World Development 29: 1623-1648.

Agrawal, A. \& Gibson, C. (1999) Enchantment and disenchantment: the role of community in natural resource conservation. World Development 27: 629-649.

Andelman, S.,\& Fagan, W.F. (2000) Umbrellas and flagships: efficient conservation surrogates or expensive mistakes? Proceedings of the National Academy of Sciences of the United States of America 97: 5954-5959.

Armbrecht Forbes, A. (1995) Heirs to the land: mapping the future of the Makalu-Barun. Cultural Survival Quarterly (Winter): 69-71.

Arvelo-Jiménez, N. \& Conn, K. (1995) The Ye'kuana self-demarcation process. Cultural Survival Quarterly (Winter): 40-42.

Balmford, A., Mace, G., \& Ginsberg, J. (1998) The challenges to conservation in a changing world: putting processes on the map. In: Conservation in a Changing World, eds. A. Balmford, G. Mace, \& J. Ginsberg, pp.1-28. Cambridge, UK: Cambridge University Press.

Balmford, A., Leader-Williams, N., \& Green, J. (1995) Parks or arks: where to conserve large threatened mammals? Biodiversity and conservation 4: 595-607.

Balram, S., Dragicevic, S., \& Meredith, T. (2004) A collaborative GIS method for integrating local and technical knowledges in establishing biodiversity conservation priorities. Biodiversity and Conservation 13: 1195-1208.

Beier, P. \& Noss, R.F. (1998) Do habitat corridors provide connectivity? Conservation Biology 12: 1241-1252.

Berger, J. (2004) The last mile: how to sustain long distance migration in mammals. Conservation Biology 18: 320-331.

Berkes, F., Kislaioglu, M., Folke, C. \& Gadgil, M. (1998) Exploring the basic ecological unit: ecosystem-like concepts in traditional societies. Ecosystems 1: 409-415. 
Boothby, J. (2002). Lines on maps: issues in designative wildlife-conservation areas. Bulletin of the Society of University Cartographers 36: 45-49.

Brandon, K., Redford, K.H. \& Sanderson, S.E. (1998) Introduction. In: Parks in Peril: People, Politics, and Protected Areas, eds. K. Brandon, K.H. Redford, and S.E. Sanderson, pp. 1-23. Washington, DC: The Nature Conservancy and Island Press.

Braun, B. \& Castree, N. (1998) Remaking Reality: Nature at the Millennium. London \& New York: Routledge.

Brooks, T.M., Mittermeier, R.A., de Fonseca, G.A.B., Gerlach, J., Hoffmann, M., Lamoreux, J.F., Mittermeier, C.G., Pilgrim, J.D., \& Rodrigues, A.S.L. (2006) Global biodiversity conservation priorities, Science 313: 58-61.

Brown, K. (1997) Plain tales from the grasslands: extraction, value and utilization of biomass in Royal Bardia National Park, Nepal. Biodiversity and Conservation 6: 59-74.

Chapin, M. (2004) A challenge to conservationists. World Watch 17: 17-31.

CITES. (2006) The CITES species. Available online at: http://www.cites.org/eng/disc/species.shtml. Accessed: 21 September, 2006.

Clapp, R.A. (2004) Wilderness ethics and political ecology: remapping the Great Bear Rainforest. Political Geography 23: 839-862.

Colchester, M. (1996) Beyond 'participation': indigenous peoples, biological diversity conservation and protected management. Unasylva 4.

Copolillo, P., Gomez, H., Maisels, F. \& Wallace, R. (2004) Selection criteria for suites of landscape species as a basis for site-based conservation. Biological Conservation 115: 419-430.

Cowling, R., Knight, A., Faith, D., Ferrier, S., Lombard, A., Driver, A., Rouget, M., Maze, K.,\& Desmet, P. (2004) Nature conservation requires more than a passion for species. Conservation Biology 18: 1674-1676.

Cronon, W. (1995) The trouble with wilderness: or, getting back to the wrong nature. In: Uncommon Ground: Toward Reinventing Nature, ed. W. Cronon, pp. 69-90. New York: W.W. Norton \& Company.

Curtin, C. (2002) Integration of science and community-based conservation in the Mexico/U.S. borderlands. Conservation Biology 16: 880-886.

Danby, R.K. (1997) International transborder protected areas: experience, benefits, and opportunities. Environments 25: 1-14. 
Ervin, J. (2003) Protected area assessments in perspective. Bioscience 53: 819-822.

Fagergren, F. J. (1998) Big Cypress National Preserve: the great compromise. In: Stewardship across boundaries, eds. R.L. Knight, and P.B. Landes, 199-215. Washington, DC: Island Press.

Goldman, M. (2003) Partitioned nature, privileged knowledge: community-based conservation in Tanzania. Development and Change 34: 833-862.

Groves, C., Jensen, D., Valutis, L., Redford, K., Shaffer, M. Scott, J.M., Baumgartner, J., Higgins, J., Beck, M., Anderson, M. (2002) Planning for biodiversity conservation: Putting conservation science into practice. Bioscience 52: 499-512.

Groves, C., Valutis, L., Vosick, D., Neely, B., Wheaton, K., Touval, J., \& Runnels, B. (2000) Designing a Geography of Hope: A Practitioner's Handbook for Ecoregional Conservation Planning. The Nature Conservancy.

Halpern, B.S., Pyke, C.R., Fox, H.E., Haney, J.C., Schlaepfer, M.A., \& Zaradic, P. (2006) Gaps and mismatches between global conservation priorities and spending. Conservation Biology 20: 56-64.

Halpin, P.N. (1997) Global climate change and natural-area protection: management responses and research directions. Ecological Applications 7: 828-43.

Hanks, J. 2000. The Role of Transfrontier Conservation Areas in Southern Africa in the Conservation of Mammalian Biodiversity. Cambridge University Press, Cambridge, UK.

Hannah, L., Midgley, G., Andelman, S., Araújo, M., Hughes, G., Martinez-Meyer, E., Pearson, R., \& Williams, P. (2007) Frontiers in Ecology and the Environment 5: 131-138.

Harris, G.M., Jenkins, C.N., \& Pimm, S.L. (2005) Refining biodiversity conservation priorities. Conservation Biology 19: 1957-1968.

Harris, L., \& H.D. Hazen. (2006) Power of maps: (counter)mapping for conservation. Acme 4: 99-130.

Harley, J.B. (1989) Deconstructing the map. Cartographica 26: 1-20.

Hazen, H.D. \& Anthamatten, P.J. (2004) Representation of ecoregions by protected areas at the global scale. Physical Geography 25: 499-512.

Hess, G., \& King, T. (2002) Planning open spaces for wildlife I. Selecting focal species using a Delphi survey approach. Landscape \& Urban Planning 58: 25-40.

Hodgson, D., \& Schroeder, R. (2002) Dilemmas of counter-mapping community resources in Tanzania. Development and Change 33: 79-100. 
Johnson, N. (1995) Biodiversity in the Balance: Approaches to Setting Geographic Conservation Principles. Washington, D.C.: Biodiversity Support Program, World Wildlife Fund.

Kareiva, P. \& Marvier, M. (2003) Conserving biodiversity coldspots. American Scientist 91: 344-351.

Katz, C. (1998) Whose nature, whose culture? Private productions of space and the 'preservation' of nature. In: Remaking Reality: Nature at the Millennium, eds. B. Braun and N. Castree, pp. 46-63. New York: Routledge.

Kintsch, J.A., \& Urban, D.L. (2002) Focal species, community representation, and physical proxies as conservation strategies: a case study in the Amphibolite Mountains, North Carolina, U.S.A. Conservation Biology 16: 936-947.

Knight, A.T., Driver, A., Cowling, R.M., Maze, K., Desmet, P.G., Lombard, A.T., Rouget, M., Botha, M.A., Boshoff, A.F., Castley, J.G., Goodman, P.S., MacKinnon, K., Pierce, S.M., Sims-Castley, R., Stewart, W.I., \& Von Hase, A. (2006) Designing systematic conservation assessments that promote effective implementation: best practice from South Africa. Conservation Biology 20: 739-750.

Lawler, J.J., Aukema, J.E., Grant, J.B., Halpern, B.S., Kareiva, P., Nelson, C.R., Ohleth, K., Olden, J., Schlaepfer, M.A., Silliman, B.R., \& Zaradic, P. 2006. Conservation science: a 20-year report card. Frontiers in Ecology and the Environment 4: 473480.

Lefroy, E.C., and Smith, F.P. (2004) The biodiversity value of farming systems and agricultural landscapes. Pacific Conservation Biology 10: 80-87.

Lombard, A., Cowling, R., Pressey, R., \& Rebelo, A. 2003. Effectiveness of land classes as surrogates for species in conservation planning for the Cape Floristic Region. Biological Conservation 112: 45-62.

Margules, C., \& R. Pressey. (2000) Systematic conservation planning. Nature 405: 243253.

Maya People of Southern Belize. (1997) Maya Atlas: The Struggle to Preserve Maya Land in Southern Belize. Toledo: Maya Cultural Council.

Mazzotta, M., Magnuson, G., Opaluch, J.J., \& Johnston, R. (2002) Setting priorities for coastal wetland restoration. Earth System Monitor 12: 1-6.

McGinnis, M.V. (1999) Bioregionalism. London and New York: Routledge.

Moenting, A.E., \& D.W. Morris. (2006) Disturbance and habitat use: is edge more important than area? Oikos 115: 23-32.

Monmonier, M. (1996) How to Lie with Maps. Chicago: University of Chicago Press. 
Moore, J., Balmford, A., Allnutt, T., \& Burgess, N. (2004) Integrating costs into conservation planning across Africa. Biological Conservation 117: 343-350.

Myers, N., Mittermeier, R.A., Mittermeier, C.G., da Fonseca G.A.B., \& Kent, J. (2000) Biodiversity hotspots for conservation priorities. Nature 403: 853-858.

Naughton-Treves, L., Holland, M.B., \& Brandon, K. (2005). The role of protected areas in conserving biodiversity and sustaining local livelihoods." Annual Review of Environmental Resources 30: 219-252.

Neumann, R. (1997) Primitive ideas: protected area buffer zones and the politics of land in Africa. Development and Change 28: 559-582.

Neumann, R. (1995) Ways of seeing Africa: colonial recasting of African society and landscape in Serengeti National Park. Ecumene 2: 149-169.

Neumann, R. (1992) Rural ecology of wildlife conservation in the Mt. Meru area of northeast Tanzania. Land Degradation and Rehabilitation 3: 85-98.

Newmark, W.D. (1995) Extinction of mammal populations in western North American national parks. Conservation Biology 9: 512-526.

Nietschmann, B. (1995) Defending the Miskito Reefs with maps and GPS. Cultural Survival Quarterly (Winter): 34-37.

Noss, R.F. (2001) Beyond Kyoto: forest management in a time of rapid climate change. Conservation Biology 15: 578-590.

Noss, R.F. (2000) Maintaining the ecological integrity of landscapes and ecoregions. In: Ecological Integrity: Integrating Environment, Conservation, and Health, eds. D. Pimentel, L. Westra, \& R.F. Noss, pp. 191-208. Washington, DC: Island Press.

O'Connor, C., Marvier, M., \& Kareiva, P. (2003) Biological vs. social, economic and political priority-setting in conservation. Ecology Letters 6: 706-711.

Olson, D.M., Dinserstein, E., Wikramanayake, E., Burgess, N., Powell, G., Underwood, E., d'Amico, J., Itoua, I., Strand, H., Morrison, J., Loucks, C., Allnutt, T., Ricketts, T., Kura, Y., Lamoreux, J., Wettengel, W., Hedao, P., \& Kassem, K. (2001) Terrestrial ecoregions of the world: a new map of life on earth. Bioscience 51: 933-938.

Olson, D., \& Dinerstein, E. (1998) The Global 200: a representation approach to conserving the earth's most biologically valuable ecoregions. Conservation Biology 12: 502-512.

Peluso, N.L. (1993) Coercing conservation? The politics of state resource control. Global Environmental Change 3: 199-216. 
Pintea, L. 2002. The ecology, history and politics of a controversial boundary: reflections on an experience of remapping Gombe National Park, Tanzania. MacArthur Consortium Conference, On the Map: Cartography, Geography, Politics. Stanford, CA: Stanford University.

Pressey R. \& Cowling R. (2001) Reserve selection algorithms and the real world. Conservation Biology 15: 275-77.

Ray, N., Lehmann, A., \& Joly, P. (2002) Modeling spatial distribution of amphibian populations: a GIS approach based on habitat matrix permeability. Biodiversity and Conservation 11: 2143-2165.

Reddy, S., \& Dávalos, L.M. (2003) Geogaphical sampling bias and its implications for conservation priorities in Africa. Journal of Biogeography 30: 1719-1727.

Ricketts, T.H., Dinerstein, E., Olson, D.M., Loucks, C.J., Eichbaum, W., DellaSala, D., Kavanagh, K., Hedao, P., Hurley, P.T., Carney, K.M., Abell, R. \& Walters, S. (1999) Terrestrial Ecoregions of North America: A Conservation Assessment. Washington, DC: Island Press.

Ricketts, R., \& Imhoff, M. (2003) Biodiversity, urban areas, and agriculture: locating priority ecoregions for conservation. Conservation Ecology 8: 1. Available at: http://www.consecol.org/vol8/iss2/art1. Date accessed: June 12, 2007.

Ridder, B. (2007) The naturalness versus wildness debate: ambiguity, inconsistency, and unattainable objectivity. Restoration Ecology 15: 8-12.

Roberts, C., Andelman, S., Branch, G., Bustamante, R., Castilla, J., Dugan, J., Halpern, B., Lafferty, K., Leslie, H., Lubchenco, J., McArdle, D., Possingham, H., Ruckelshaus, M., \& Warner, R. (2003) Ecological criteria for evaluating candidate sites for marine reserves. Ecological Applications 13: S199-S214.

Sanderson, E., Redford, K., Vedder, A., Coppolillo, P. \& Ward, S. (2002) A conceptual model for conservation planning based on landscape species requirements. Landscape and Urban Planning 58: 41-56.

Savitsky, B. (1998) Overview of gap analysis. In: GIS Methodologies, eds., B Savitsky \& T. Lacher, 151-157. New York: Columbia University Press.

Schwartz, M. (1994) Conflicting goals for conserving biodiversity: Issues of scale and value. Natural Areas Journal 13: 213-216.

Scott, J.M., Abbitt, R.J.F., \& Groves, C.R. (2001) What are we protecting? The US conservation portfolio. Conservation Biology in Practice 2: 18-19.

Shafer, C.L. (1999) National park and reserve planning to protect biological diversity: some basic elements. Landscape and Urban Planning 44: 123-153. 
Sheil, D., Puri, R., Wan, M., Basuki, I., van Heist, M., Liswanti, N., Rukmiyati, Rachmatika, I., \& Samsoedin, I. (2006) Recognizing local people's priorities for tropical forest biodiversity. Ambio 35: 17-24.

Simberloff, D. (1998) Flagships, umbrellas, and keystones: is single-species management passé in the landscape era? Biological Conservation 83: 247-257.

Sinclair, A.R.E., Ludwig, D., \& Clark, C.W. (2000) Conservation in the real world. Science 289: 1875.

Singleton, P.H., Gaines, W.L.. \& Lehmkuhl, J.F. (2002) Landscape permeability for large carnivores in Washington: a geographic information system weighteddistance and least-cost corridor assessment. Res. Pap. PNW-RP-549. Portland, OR: U.S. Department of Agriculture, Forest Service, Pacific Northwest Research Station. 89 p.

Smith, R.J., Muir, R.D.J., Walpole, M.J., Balmford, A., \& Leader-Williams, N. (2003) Governance and the loss of biodiversity. Nature 426: 67-70.

Soto, C.G. (2001) The potential impacts of global climate change on marine protected areas. Reviews in Fish Biology and Fisheries 11: 181-95.

Soulé, M. \& Terborgh, J. (1999) Continental Conservation: Scientific Foundations of Regional Reserve Networks. Washington, D.C.: Island Press.

Spence, M.D. (1999) Dispossessing the Wilderness: Indian Removal and the Making of the National Parks. New York: Oxford University Press.

Steinberg, P. (2001) The Social Construction of the Ocean. Cambridge: Cambridge University Press.

Sunderlin, W.D., Angelsen, A., Belcher, B., Burgers, P,. Nasi, R., Santoso, L., \& Wunder, S. (2005). Livelihoods, forests and conservation in developing countries: An overview. World Development 33: 1383-1402.

Tchouto, M.G.P, Yemefack, M., De Boer, W.F., De Wilde, J.J.F.E., Van Der Maesen, L.J.G., \& Cleef, A.M. (2006) Biodiversity hotspots and conservation priorities in the Campo-Ma'an Rain Forests, Cameroon. Biodiversity and Conservation 15: 1219-1252.

Terborgh, J., \& van Schaik, C. (2002) Why the world needs parks. In: Making Parks Work: Strategies for Preserving Tropical Nature, eds. J. Terborgh, C. van Schaik, L. Davenport, and M. Rao, pp. 3-14. Washington: Island Press.

Theberge, J.B. (1989) Guidelines to drawing ecologically sound boundaries for national parks and nature reserves. Environmental Management 13: 695-702.

Turner, M.D. (2006) Shifting scales, lines and lives: the politics of conservation science 
and development in the Sahel. In: Globalization and Geographies of Conservation, ed. K. Zimmerer, pp.. Minneapolis: University of Minnesota Press.

Turner, M.D. (1999) No space for participation: pastoralist narratives and the etiology of park-herder conflict in southeastern Niger. Land Degradation and Development 10: 345-363.

Valavanis V., Kapantagakis, A., Katara, I., \& Palialexis, A. (2004) Critical regions: a GIS-based model for marine productivity hostpots. Aquatic Science 66: 139-148.

Vale, T.R. (1988) No romantic landscapes for our national parks? Natural Areas Journal 8: $115-117$.

Vandergeest, P. (1996) Mapping nature: territorialization of forest rights in Thailand. Society and Natural Resources 9: 159-175.

Vandermeer, J., \& Perfecto, I. (1995) Breakfast of Biodiversity: The Truth about Rainforest Destruction. Oakland: Food First Books.

WDPA Consortium. (2006) World Database on Protected Areas 2006. Copyright World Conservation Union (IUCN) and UNEP-World Conservation Monitoring Centre (UNEP-WCMC), 2006. http://sea.unep-wcmc.org/wdbpa/index.htm. Last accessed 12 July, 2006.

Weis, T. (2000) Beyond peasant deforestation: environment and development in rural Jamaica. Global Environmental Change 10: 299-305.

Whittaker, R.J., Araújo, M.B., Jepson, P., Ladle, R., Watson, J.E.M., \& Willis, K.J. (2005) Conservation biogeography: assessment and prospect. Diversity and Distributions 11: 3-23.

Woodley, S. (1997) Science and protected area management: an ecosystem-based perspective. In: National Parks and Protected Areas: Keystones to Conservation and Sustainable Development, eds., J.G. Nelson \& R. Serafin, pp.11-21. Berlin: Springer-Verlag.

Zander, P., \& Kachele, H. (1999) Modeling multiple objectives of land use for sustainable development. Agriculture Systems 59: 311-325.

Zimmerer, K. (2000) The reworking of conservation geographies: nonequilibrium landscapes and nature-society hybrids. Annals of the Association of American Geographers 90: 356-369.

Zimmerer, K.S., Galt, R.E., \& Buck, M.V. (2004) Globalization and multi-spatial trends in the coverage of protected-area conservation (1980-2000). Ambio 33: 520-529. 